\title{
OBSERVATIONS ON RENAL FUNCTION IN ACUTE EXPERIMENTAL UNILATERAL NEPHRI'TIS *
}

\author{
W. C. QUINBY, M.D., AND R. FITZ, M.D. \\ BOSTON
}

The study of renal function during the past few years has occupied considerable attention in both clinical and experimental laboratories. A number of different tests have been advocated by different observers, but so far no attempt has been made, in experimental surgery, to compare a variety of these tests on the same animal at the same time. This paper describes experiments which were made to establish an acute unilateral nephritis in dogs, and records the studies on renal function in this condition to determine which of the tests used most commonly in the surgical clinic are of greatest practical value in the diagnosis of one-sided lesions of varying severity.

An experimental one-sided nephritis has already been produced. In 1883, Ribbert ${ }^{1}$ excised the medulla of one kidney in rabbits in his experiments on renal physiology. Boyd ${ }^{2}$ and Oppenheimer ${ }^{3}$ confirmed this method of producing a unilateral lesion by using the same technic. Oppenheimer's work is of especial interest in regard to functional studies on nephritis. By removing the cortex of one kidney, he found that the secretion of urine on that side stopped. But when the medulla was removed, there was an increased output of urine from the affected kidney which contained more sodium chlorid and had a lower freezingpoint than the urine from the normal side. Yet the glycosuria resulting from subcutaneous injections of phloridzin was diminished. This, he considered, afforded evidence in favor of tubular resorption. Schlayer's ${ }^{4}$ method for producing unilateral lesions consisted of the injection of epinephrin into various points of the renal parenchyma. As a result, he obtained a contracted kidney. Hirsch and Maschke ${ }^{5}$

* Stubmitted for publication July 23, 1914.

* From the Laboratory of Surgical Research, Harvard Medical School, and the Medical Clinic of the Peter Bent Brigham Hospital.

1. Ribbert: Ueber Resorption von Wasser in der Marksubstance der Niere, Virchow's Arch. f. path. Anat., 1883, xciii, 169.

2. Boyd: Some Experiments on the Functions of the Medulla of the Kidney, Jour, Physiol., 1902, xxviii, 76.

3. Oppenheimer: Experimentelle Untersuchungen über die Nierentätigkeit und ihre Beziehung zur funktionellen Diagnostik, Verhandl. d. deutsch. Gesselsch. f. Urol., 1909, ii, 289.

4. Schlayer: Ueber künstliche Erzeugung von Schrumpfniere, München. med. Wchnschr., 1909, lvi, 687.

5. Hirsch and Maschke: Experimentelle Untersuchungen über Nephritis, Berl. klin. Wchnschr., 1912, xlix, 145. 
introduced the actual cautery into different parts of one kidney and obtained foci of scar tissue on that side. Brewer ${ }^{6}$ caused pyelonephritis by the injection of pathogenic bacteria into the proximal segment of the ligated ureter, and Stewart ${ }^{7}$ made a similar picture by the implantation of the ureter into the wall of the intestine. These various experiments, however, were designed to produce a chronic nephritis or depended on infection or on the introduction of artificial factors which would render the animals unfit for further studies.

For our purposes, Ribbert's ${ }^{8}$ later method, as used by Baehr, ${ }^{9}$ promised more satisfactory results. Ribbert exposed the renal artery of one kidney in rabbits and injected directly into it a solution of iodin which was perfused through the whole kidney by the arterial blood. Baehr, following this technic, injected the renal artery in the same way with iodin, croton oil, potassium chromate and uranium. nitrate. The last substance produced marked unilateral glomerular lesions in rabbits, with little tubular destruction. By different degrees of dosage and by varying the length of time which the disease was allowed to run, various stages of acute, subacute or chronic one-sided nephritis were obtained. In our experiments, Baehr's method with t1ranium nitrate was followed with a few changes.

The introduction of ureteral catheterization into renal surgery opened up a brilliant field for the study of the urine excreted simultaneously from each kidney. By this method, the urine from one kidney could be compared with the urine from the other, and a number of different observations could be made to determine which kidney showed an abnormal function, and to what extent it was damaged compared with the other kidney. It is known that there is a certain variation in the amount of urine and solids excreted from the two kianeys over short intervals of time. But Albarran ${ }^{10}$ and Kapsammer ${ }^{11}$ have found that these differences diminish with the length of time of observation, and that normally, in an hour, nearly the same amount of urine and solids comes from each side.

6. Brewer: The Present State of Our Knowledge of Acute Renal Infections; With a Report of Some Animal Experiments, Jour. Am. Med. Assn., 1911, lvii, 179.

7. Stewart: A Study of Ascending Infection of the Kidney Carried Out by the Method of Transplanting the Ureters into the Intestines, Univ. Penn. Med. Bull., 1911, xxiii, 233.

8. Ribbert: Untersuchungen über die normale and pathologische Physiologie und Anatomie der Niere, Bibliotheca Medica, 1896, Part C, No. 4, p. 1.

9. Baehr: Ueber experimentelle Glomerulonephritis (Ein Beitrag zur Lehre der Schrumpfniere), Beitr. z. path. Anat. u. z. allg. Path., 1913, lv, 545.

10. Albarran: Recherches sur le fonctionment normal comparé des deux reins, Ann. d. mal. d. org. genito-urin., 1904, xxii, 81.

11. Kapsammer: Uber Ureterenkatheterismus und funktionelle Nierendiagnostik, Wien. klin. Wchnschr., 1903, xvi, 1417. 
Certain physical, chemical and excretory properties of the urine from the two kidneys have been compared to estimate differences in renal function of the two organs under pathological conditions. Von Korány ${ }^{12}$ introduced the determination of the freezing-point of urine as an index for the functional capacity of the two kidneys. In general, he found that the concentration of the urine was less as the severity of the disease increased. Many subsequent observers have applied this method as a test for function in unilateral disease. The results obtained from it have disagreed. The bulk of evidence shows that the freezingpoint of urine determines which kidney is functioning to best advantage, but that this test is by no means quantitatively accurate.

Turner ${ }^{13}$ made observations on the electrical conductivity of urine under various conditions. He discovered that its electrical resistance in ohms was inversely proportional to its sodium chlorid concentration, and believed that this test, on account of its relative simplicity and the small amount of urine required in performing it, would be valuable in surgery as a means of studying the function of the individual kidney. Loewenhardt ${ }^{14}$ confirmed these results by showing that under normal conditions the electrical resistance of the urine from each kidney was nearly the same, but when the function of the two kidneys varied, marked differences in electrical conductivity of the separated urines were foind. A powerful advantage for this test, he declared, lay in the fact that since small amounts of urine were needed, the length of time for ureteral catheterization could be materially shortened. These findings, however, have not been accepted by many observers. Gottstein $^{15}$ objects to the test after careful review of the literature and from his own experience. Since electrical conductivity does not deal with the number of molecules in solution, but merely with the number of ions, it offers no information as to the total concentrative powers of the kidney, and tells but little more in regard to the degree of renal injury than a specific gravity determination.

The excretion of sodium chlorid, nitrogen or urea from the two sides has been compared in suspected unilateral disease. The amount of nitrogen or urea put out has given the most accurate information in regard to the degree of disease. While Albarran found in normal indi-

12. Von Korányi: Physiologische und klinische Untersuchungen über der osmotischen Druck thierischen Flüssigkeiten, Ztschr. f. klin. Med., 1897, xxxiii, 1 ; ibid., 1898, xxxiv, 1.

13. Turner: The Electrical Conductivity of the Blood and Urine in Health and in Disease, and as a Test of the Functional Efficiency of the Kidney, Edinburgh Med. Jour., 1907, N. S., xxi, 318.

14. Loewenhardt: Weitere Ergebnisse der Bestimmung der elektrischen Leitfähigkeit des Harnes, Deutsch. Gesellsch. f. Urol., 1909, ii, 281.

15. Gottstein: Der heutige Stand der funktionellen Nierendiagnostik, Ergebn. d. Chir. u. Orthopädie, 1911, ii, 417. 
viduals that the actual amount of urea from the two kidneys was nearly the same over a given interval, Barringer ${ }^{16}$ showed that in disease its total excretion varied, diminishing in almost direct proportion to the degree of injury found in one or the other organ. Many other writers have confirmed this observation.

Of the substances found in the urine under normal conditions, Wohlgemuth $^{17}$ has advocated the estimation of diastase as a test for the function of the two kidneys. He believes that this determination affords a simple means for estimating differences in function of the two kidneys when one is diseased, and that the amount of ferment excreted varies directly with the degree of injury on the affected side. His results in bilateral nephritis have been substantiated by von Benczur, ${ }^{18}$ Geyelin, ${ }^{19}$ Hirata, ${ }^{20}$ Marino, ${ }^{21}$ Rosentha ${ }^{22}$ and Wynhausen. ${ }^{23}$ Few confirmatory studies have been made with the test in surgery except by Geraghty, Rowntree and Carey. ${ }^{24}$ At present the true value of this method is undetermined.

Finally, Palmer and Henderson ${ }^{25}$ have found that the urinary acidity as estimated by its hydrogen ion concentration shows marked variation in different types of nephritis. It seemed possible that this test in unilateral disease might give interesting results.

16. Barringer: The Comparison of the Total Urea Excreted by Each Kidney in Surgical Diseases of These Organs; Its Value in Estimating the Functional Capacity and Pathological Changes of Kidneys, Surg., Gynec. and Obst., 1908, vii, 651 .

17. Wohlgemuth: Ueber eine neue Methode zur quantitativen Bestimmung des diastatischen Ferments, Biochem. Ztschr., 1908, ix, 1; Beitrag zum Verhalten der Diastase im Urin, ibid., 1909, xxi, 432; Experimentelle Beiträge zur Prüfung der Nierenfunktion, Ztschr. f. Urol., 1911, v, 801.

18. Von Benczur: Beitrag zur klinischen Verwertbarkeit der Diastasemenge in Blutserum und Urin, Wien. klin. Wchnschr., 1910, xxiii, 890.

19. Geyelin: A Clinical Study of Amylase in the Urine, with Special Reference to the Phenolsulphonephthalein Test, The Archives Int. Med., 1914, xiii, 96.

20. Hirata: Beitrag zum Verhalten der Diastase im Blut und im Urin beim Kaninchen, Biochem. Ztschr., 1910, xxviii, 23.

21. Marino: Ueber die diagnostische Bedeutung der Diastaseausscheidung im Harn, Deutsch. Arch. f. klin. Med., 1911, ciii, 325.

22. Rosenthal: Zur Frage der Ausscheidung von disastatischem Ferment im Urin, Deutsch. med. Wchnschr., 1911, xxxvii, 923.

23. Wyrhausen: Quantitative Diastasebestinmungen im Harn, besonders ihre Beziehung zur Nephritis und zum Diabetes mellitus, Berl. klin. Wchnschr., 1910, xlvii, 2107.

24. Geraghty, Rowntree and Carey: The Value and Iimitation of Diastase, Urea and Phthalein in Estimating Renal Function in Association with Ureteral Catheterization, Ann. Surg., 1913, lviii, 800.

25. Henderson and Palmer: On the Intensity of Urinary Acidity in Normal and Pathological Conditions, Jour. Biol. Chem., 1913, xiii, 393; Clinical Studies on Acid Base Equilibrium and the Nature of Acidosis, Thf Archives Int. Med., 1913, xii, 153 . 
Various substances have been injected into the body and their excretion in the urine followed as tests to illustrate the comparative functions of the two kidneys. Such tests in general have depended on the kidney's ability to rid itself of dyes or drugs or to produce a glycosuria from phloridzin.

Many dyes have been tried as tests for renal function, but at present two are generally accepted as being most valuable. Voelcker and Joseph $^{2 i}$ injected a solution of indigocarmin intramuscularly, noted its time of appearance in the urine, and determined by colorimetry the total amount excreted in a given interval. In general, both the time of appearance and the amount excreted varied with the severity of the existent nephritis. Their results have been confirmed by Baetzner, ${ }^{27}$ Ehrich, ${ }^{28}$ Roth, ${ }^{29}$ and Tanaka, ${ }^{30}$ who emphasized that the time of appearance, though usually important, might be misleading in certain cases; and that, therefore, the actual amount excreted was of greater significance. Gottstein considers indigocarmin the most satisfactory single test for renal function which is used.

Rowntree and Geraghty ${ }^{31}$ made use of phenolsulphonephthalein as a test for renal function, showing it to be an excellent index of both unilateral and bilateral kidney disease. Their original work has been supported by many observers, among others Behrenroth and Frank, ${ }^{32}$ Cabot and Young, ${ }^{33}$ Deutsch ${ }^{34}$ and Keyes and Stevens. ${ }^{35}$

Von Mering ${ }^{36}$ discovered that a characteristic of phloridzin, following its subcutaneous injection, was the production of a glycosuria in

26. Voelcker and Joseph: Funktionelle Nierendiaguostik ohne Ureterenkatheter, München. med. Wchnschr., 1903, 1, 2081.

27. Baetzner: Funktionelle Nierendiagnostik, Berl. klin. Wchnschr., 1912, lxix, 1521 .

28. Ehrich: Diagnostischer Wert der Indigokarminprobe bei chirurgischen Nierenerkrankungen, Deutsch. med. Wchnschr., 1911, xxxvii, 526.

29. Roth: Ueber die Unzulänglicheit der Chromocystaskopie für die funktionelle Nierendiagnostik, Ztschr. f. Urol., 1911, v, 439.

30. Tanaka: Bestimmung zur Indigocarminreaktion für die funktionelle Nierendiagnostik, Ztschr. f. Urol., 1911, v, 82.

31. Rowntree and Geraghty: An Experimental and Clinical Study of the Functional Activity of the Kidneys by Means of Phenolsulphonephthalein, Jour. Pharmacol. and Exper. Therap., 1910, i, 579.

32. Behrenroth and Frank: Klinische und experimentelle Untersuchungen über die Funktion der Niere mit Hülfe der Phenolsulphonephthalein Probe, Ztschr. f. exper. Path. and Therap., 1913, xiii, 72.

33. Cabot and Young: Phenolsulphonephthalein as a Test of Renal Function, Tr. Am. Assn. G.-U. Surg., 1911, vi, 136.

34. Deutsch: Funktionelle Nierenprüfung mittels Phenolsulphonephthalein, Wien. klin. Wchnschr., 1912, xxv, 1217.

35. Keyes and Stevens: A Clinical Study of Renal Function by Means of Phenolsulphonephthalein, Am. Jour. Urol., 1911, vii, 367.

36. Von Mering: Ueber kunstlichen Diabetes, Centralbl. f. d. med. Wissensch., 1885, xxiii, 531 . 
actively functioning kidneys. Casper and Richter ${ }^{37}$ made use of this fact as the basis for a test of renal function. They injected phloridzin subcutaneously, noted the appearance time of sugar in the urine coming from each kidney, and compared the total amount of sugar excreted over a given period of time. They believed that, if one kidney were diseased, it put out less sugar than the normal kidney, the discrepancy varying in proportion to the severity of the lesion. Thus the test was not only qualitative, but also quantitative. Other observers, however, have not confirmed Casper and Richter. Though this test has many adherents, it is believed that the phloridzin test alone is not of great value.

From this short review, it is seen that tests for renal function fall into two distinct groups. The first group depends on variations in the physical and chemical properties of the urine coming from each kidney. The most important of such tests are the determination of the freezing point of the urine and the comparative amounts of nitrogen, urea and diastase excreted in a known period of time. The second group of tests depends on the ability of the kidney to excrete from the blood abnormal substances which are introduced into the circulation. The most important of this group are the indigocarmin and phenolsulphonephthalein tests. The phloridzin glycosuria test, though strictly speaking not belonging in this group, may be included for convenience.

A number of clinical observations have been made to compare certain of these tests to decide which single one is of the greatest value. Casper and Richter compared the phloridzin test with freezing-point determinations in a number of cases. The results of these tests agreed closely. When one kidney was diseased the molecular concentration of that urine was low, the glycosuria was delayed in appearance and small in amount. When no lesion existed, the concentration of the two urines was nearly the same and the time of appearance of sugar and the amount excreted from both sides were alike. Roth ${ }^{38}$ made use of indigocarmin, phloridzin and freezing point determinations in a scries of comparative studies. The excretion of indigocarmin and the amount of phloridzin glycosuria paralleled each other and bore a close relationship to the freezing point. All tests pointed out the diseased kidney. Yet Roth, ${ }^{29}$ in a later paper, expressed the opinion that the indigocarmin test was less delicate than the other two. Unterberg ${ }^{39}$ compared the excretion of sodium chlorid and urea with freezing-point

37. Casper and Richter: Functional Diagnosis of Kidney Disease, 1903, P. Blakiston's Sons \& Company, Philadelphia.

38. Roth: Zur Bewertung der Indigkarminmethode für funktionelle Nierendiagnostik, Verhandl. d. deutsch. Gessellsch. f. Urol., 1909, ii, 305.

39. Unterberg: Der praktische Wert der funktionellen Nierenuntersuchungen bei chirurgischen Erkrankungen der Nieren, Ztschr. f. Urol., 1909, iii, 687. 
determinations and with the phloridzin test. There was a parallelism between all the tests. The freezing point varied with the amount of urine obtained, but in cases of unilateral disease it was always nearer to zero on the diseased side than on the normal side. In such cases, the chlorid and urea excretions were ustually diminished.

Baetzner compared the excretion of indigocarmin with the freezing point and found that as the excretion of the dye diminished, the molecular concentration of the urine was less, and that both these tests ran parallel with the degree of renal injury. Goodman and Kristeller, ${ }^{40}$ and Thomas ${ }^{41}$ compared the excretion of phenolsulphonephthalein with that of indigocarmin in one-sided kidney disease. The two dyes were eliminated in amounts closely parallel; the total amount of indigocarmin excreted in proportion to the amount injected was approximately one-half that of phenolsulphonephthalein excreted. Keyes and Stevens compared the excretion of phenolsulphonephthalein with that of urea from separately catheterized kidneys. The cases which justified comparison gave the same results and showed the same ratio of functional ability. Stevens ${ }^{42}$ compared the phenolsulphonephthalein test with phloridzin glycosuria and with the excretion of urea. In both normal and pathological cases, these tests gave similar results. Finally, Geraghty, Rowntree and Carey compared the excretion of phenolsulphonephthalein with urea and diastase in a series of cases. They felt that the phenolsulphonephthalein test was the most significant, that diastase was of value in the majority of cases as indicating which kidney was the more diseased, and that urea estimations almost invariably corroborated the phenolsulphonephthalein findings. A patent disadvantage of the diastase test lay in the fact that dilution of the urine affected it to a more marked extent than it did the other tests - a point which Wohlgemuth has emphasized in his experiments on dogs.

Thus, on the whole, a striking parallelism appears to exist between the tests for renal function which are generally used in surgical diseases of the kidney. Although the amount of urine excreted from the two sides may vary, its molecular concentration diminishes in proportion to the severity of the disease; it contains less nitrogen, urea and diastase; the diseased kidney in proportion to its lesion is less capable of excreting indigocarmin, phenolsulphonephthalein and sugar after

40. Goodman and Kristeller: The Value of Phenolsulphonephthalein in Estimating the Functional Efficiency of the Kidneys, Surg., Gynec. and Obst., 1911, xii, 56.

41. Thomas: The Quantitative Determination of Functional Renal Sufficiency by the Duboscq Colorimeter: Indigo-Carmine versus Phenolsulphonephthalein, Am. Jour. Med. Sc., 1911, cxlii, 376.

42. Stevens: The Comparative Value of Modern Functional Kidney Tests, Jour. Am. Med. Assn., 1914, 1xii, 1544. 
the injection of phloridzin. In other words, all these various tests point to the same findings. The tests for renal function used in surgery are based on the facts that a diseased kidney is incapable of excreting solids, and that the degree of impairment of this fundamental function parallels in a general way the degree of existent disease. Therefore, the important feature in the selection of a test for renal function, when the urine from the two kidneys is compared, is to choose that one which is simplest for both surgeon and patient to perform, but which is delicate enough to point out the degree of existent disease. Tests for renal function on our dogs with unilateral nephritis were undertaken to determine this point experimentally.

\section{METHOD}

Dogs were anesthetized with morphin and ether. In a few animals, abdominal section through the left rectus incision was made under aseptic precautions. The left kidney was freed from its capsule and its artery and vein were dissected clean by scissors and by wiping with dry gauze. Every effort was made to avoid rupture of nerve fibers. Rubber-tipped serrefines were placed separately on both vein and artery. The kidney itself was then delivered through the abdominal wound in such fashion as to expose the renal artery to best advantage without undue tension. One c.c. of distilled water which contained the desired dose of uranium nitrate was then injected into the vessel from a 2 c.c. Record syringe with a fine pointed needle, the tip of which was bent at right angles. In a few cases in which the renal artery was doubled, each branch was clamped and was injected with half the dose. In other animals, only one branch of the renal artery was injected. In a few experiments, 2 or 5 c.c. of injection fluid were used.

After the artery was injected the arterial clamp was removed for a few seconds in order to distribute the uranium through the kidney substance as diffusely as possible. The slight bleeding at the point of puncture occasioned by this procedure was readily controlled, and the kidney as a whole became engorged. The arterial clamp was replaced. After intervals of from thirty seconds to five minutes, the point of the needle was inserted into the renal vein, and 5 c.c. of blood from the kidney were aspirated into the syringe. Whatever bleeding occurred around the needle point was controlled by walling-off sponges to prevent systemic absorption of the poison. Finally both the arterial and venous clamps were removed, the kidney replaced in its normal position and the wound closed according to usual methods.

Virtually, the same technic was used in all our experiments. The only modification in our later studies was to use a lumbar incision for exposing the kidney, instead of reaching it through the peritoneum. 
In this way, a smaller incision could be made, the muscles could be separated by blunt dissection without bleeding, and the kidney could be exposed and delivered into the wound through the back with slight handling. Great care was used throughout not to traumatize the kidney.

As our primary object was to produce different degrees of pathological change, the dosage of the drug varied in individual cases. The largest amount given was $1 \mathrm{mg}$. of uranium per kilogram of body weight, the smallest dose was $1 / 20 \mathrm{mg}$. per kilogram of body weight. Slightly less than $0.1 \mathrm{mg}$. per kilogram of body weight was found to produce a well-marked nephritis in twenty-four hours; this consequently was the dosage which was used in the majority of our experiments.

A few typical protocols with photomicrographs of the two kidneys are given to demonstrate the efficacy of the technic.

Experiment 1.-Severe Nephritis.-Dog 1, weight $7 \mathrm{~kg}$.

March 16: Ether-morphin anesthesia. Left rectus incision. The left kidney was exposed and delivered through the wound after the renal vessels were dissected free and clamped. One mg. per kilogram body weight of uranium nitrate in 2 c.c. of distilled water was injected into the renal artery. The arterial clamp was removed and reapplied at once. After one minute the renal vein was punctured and the blood was removed by pressure and suction. The clamps were then removed from the vessels, the kidney was replaced in normal position and the wound sewn up.

March 17: Animal appeared in good condition. It was killed twenty-four hours after operation. The right kidney weighed $40 \mathrm{gm}$. and appeared normal. The left kidney weighed $65 \mathrm{gm}$. and was dark colored, except in minute areas scattered through the parenchyma which appeared necrotic. Specimens of tissue were obtained from both kidneys, fixed in Zenker's fluid and stained with eosin and methylene blue. Microscopic sections from the right kidney were normal. Sections from the left kidney showed areas of hemorrhagic necrosis in which the normal renal structure was lacking. In other parts many of the glomeruli showed necrosis of the capillary endothelium with fibrinous thrombi in the vessel walls. The tubular epithelium was lacking in certain parts. In others, it had desquamated into the lumen of the tubule, filling it with homogeneous necrotic material and serum. Numerous polymorphonuclear leukocytes were seen throughout the entire kidney structure. On the whole, the histological picture was that of an acute unilateral nephritis with necrosis of the kidney.

EXPfriment 2.-Well-Marked Nephritis.-Dog 4, weight $9 \mathrm{~kg}$.

March 23: Morphin-ether anesthesia. Left rectus incision. The left kidney was exposed and delivered through the wound after the renal vessels were dissected free and clamped. The renal artery was bifurcate, so that clamps were applied to each branch. Each artery was injected with $0.4 \mathrm{mg}$. (0.9 mg. per kilogram body weight) of uranium nitrate in 0.5 c.c. of distilled water. The arterial clamps were removed and reapplied at once. After three minutes the renal vein was punctured and the blood was removed by pressure and suction. The clamps were then removed from the vessels, the kidney was replaced in normal position, and the wound was sewn up.

March 24: The animal appeared in good condition. It was killed twentyfour hours after operation. The right kidney weighed $32 \mathrm{gm}$. and appeared 


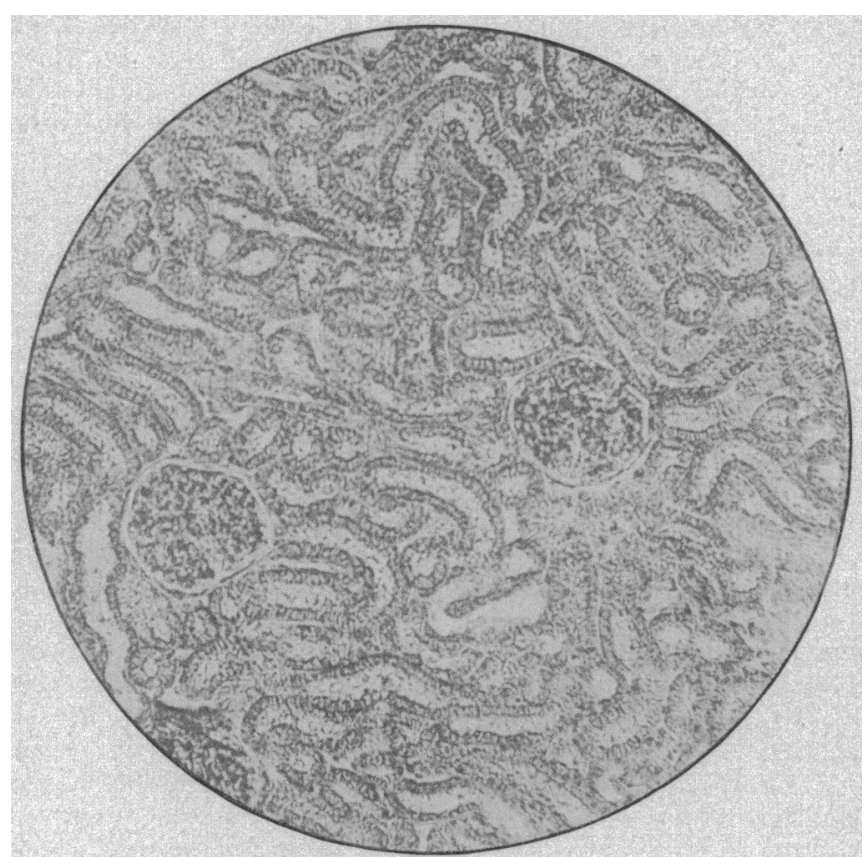

Fig. 1 (Dog 1).-Right kidney. Eosin-methylene blue staining, $\times 20$. No lesion made out.

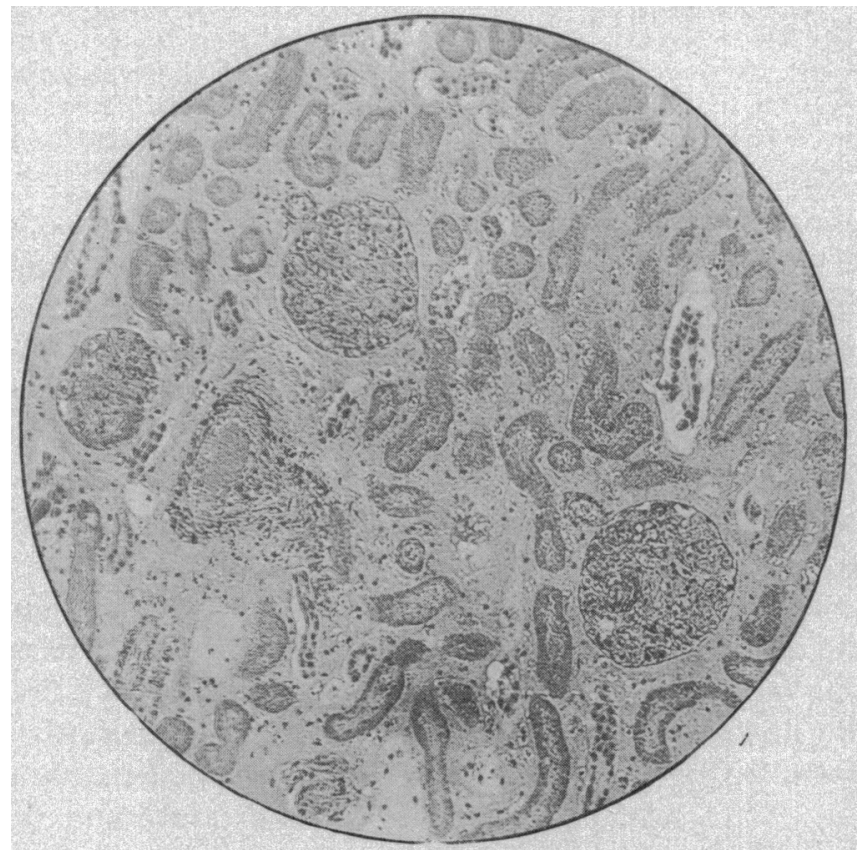

Fig. 2 (Dog 1).-Left kidney. Eosin-methylene blue staining, $\times 20$. Necrosis of glomeruli and tubules. Edema. Leukocytic infiltration. 
normal. The left kidney weighed $43 \mathrm{gm}$., and was firm and of dark color. Specimens of tissue were obtained from both kidneys, fixed in Zenker's fluid and stained with hematoxylin and eosin. Microscopic sections from the right kidney were normal. Microscopic sections from the left kidney showed considerable hemorrhage. There were a few small areas of necrosis and of polymorphonuclear leukocytic infiltration. The larger part of the kidney was much less severely damaged. The glomeruli were normal. There was considerable desquamation of epithelium and effusion of serum into the lumen of the tubules, as in the previous experiment, with the formation of similar homogeneous masses, many of which contained leukocytes. There was evidence of tubular regeneration shown by large atypical epithelial cells lining some of the tubules. No mitotic figures were seen. The histological picture, therefore, was that of a moderately severe unilateral nephritis with a small amount of necrosis, but with well-marked tubular destruction.

EXPERIMLNT 3.-Mild Nephritis.-Dog 9, weight $6.2 \mathrm{~kg}$.

April 10: Ether-morphin anesthesia, Left lumbar incision. The left kidney was exposed and delivered through the wound after the renal vessels were dissected free and clamped. The renal artery was bifurcate so that clamps were applied to each branch. Each artery was injected with $0.3 \mathrm{mg}$. $(0.1 \mathrm{mg}$. per kilogram body weight) of uranium nitrate in 2.5 c.c. of distilled water. The arterial clamps were removed and were reapplied at once. After two minutes the renal vein was punctured, and the blood was removed by pressure and suction. The clamps were then removed from the vessels, the kidney was replaced in normal position, and the wound was sewn up.

April 13: Following the operation, the animal was in good condition. It was killed seventy-two hours later. The right kidney weighed $14 \mathrm{gm}$. and the left $12 \mathrm{gm}$. In the gross, both kidneys appeared normal. Specimens of tissue were obtained from both kidneys, fixed with Zenker's fluid, and stained with hematoxylin and eosin. Microscopic sections from the right kidney were normal. Sections from the left kidney showed less acute changes than the two preceding. There was no evidence of exudation or hemorrhage. The glomeruli were normal. Many of the tubules were filled with homogeneous material like that previously described, and which appeared to come from desquamated epithelium. There was considerable formation of new epithelium, and mitotic figures could be found without difficulty.

These three typical protocols illustrate that it is possible to produce an experimental unilateral nephritis by the method described, causing different degrees of severity according to the amount of poison injected and according to the length of time the disease is allowed to exist. In all our experiments, except those in which insufficient dosage of uranium was given, similar lesions were obtained. In the entire series no pathological change was found in the normal kidney, and in only one observation was thrombosis of the injected renal artery found at necropsy. Thus the method appeared satisfactory for our purposes.

At varying intervals of from twenty-four hours to eighteen days after the initial operation, the dogs were anesthetized with paraldehyd in dosage of 1.7 c.c. per kilogram of body weight. The ureters were freed by lumbar incision and were catheterized separately with fine glass cannulas. The urine from the kidneys was collected in test-tubes. The rate of respiration, the carotid blood-pressure and the rate of urinary outflow were recorded on a kymographion according to usual technic. 
The amount of urine required for the various functional tests which were to be studied was so large that it was necessary to stimulate the kidneys by a diuretic. The animals at the beginning of the experiment were given 200 c.c. of water by stomach-tube and 10 per cent. saline solution intravenously. The initial dose used was 20 c.c.; this was repeated often enough to maintain a constant flow of urine. It was realized that this maneuver introduced an abnormal factor into the experiment. It was constant, however, since the sodium chlorid which came to the kidneys at any time was the same on each side. Therefore, the response of the two kidneys was considered as significant as though no diuretics had been used.

After the animal was once anesthetized and catheterized, a uniform rate of urinary outflow soon became established. The subsequent observations were divided into four periods of an hour each. During the first hour, the urine from the two sides was collected and measured. Its specific gravity was obtained by weight; its total sodium chlorid and nitrogen content as well as their concentration per hundred c.c. of urine were found by Volhard's method and Kjeldahl's method; the freezing-point was determined by Beckmann's method; the diastase content by Wohlgemuth's ${ }^{43}$ method; the hydrogen ion concentration by Palmer and Henderson's method.

In the second hour the phenolsulphonephthalein test was performed. Rowntree and Geraghty's original technic was used. A solution, 1 c.c. of which contained $6 \mathrm{mg}$. of the dye, was injected intramuscularly or intravenously. A small amount of alkali was added to the test-tubes which collected the urine from each kidney. The time of appearance of the dye from the two sides was observed and the total amount excreted in an hour from each kidney was estimated in Rowntree and Geraghty's modification of the Autenrieth-Königsberger colorimeter.

Prussian blue, introduced by Schroeder van der Kolk ${ }^{44}$ in histology, is recognized as being one of the standard means ${ }^{45}$ for staining the renal tubules. It seemed possible that the excretion of this dye might be used as a test for renal function in the same fashion that other dyes are used. A solution was made which contained $100 \mathrm{mg}$. of potassium ferrocyanid in 1 c.c. of water and was injected intravenously. A small amount of ferric chlorid and dilute hydrochloric acid were added to the test-tubes receiving the urine from the ureteral catheters. As soon as the ferrocyanid appeared in the urine, it was precipitated as a deep

43. Wohlgemuth and Noguchi: Experimentelle Beiträge zur Diagnostik der subcutanen Pankreasverletzungen, Berl. klin. Wchnschr., 1912, xlix, 1069.

44. Schroeder van der Kolk: Quoted by Hartung: Das Mikroskop, 1866, Vieweg und Sohn, Braunschweig, ii, 124.

45. Enzyklopädie der Mikroskopischen Technik, 1910, Urban and Schwarzenberg, Vienna, ii, 321. 
blue sediment. The time of appearance of this dye from each kidney was recorded, and the total amount excreted in one hour was quantitated in the Duboscq colorimeter by turbidometry against a standard solution of the dye precipitated in the same fashion and diluted to an appropriate bulk.

The following experiment illustrates the relative accuracy with which such readings could be obtained. A standard solution was made containing $100 \mathrm{mg}$. of Prussian blue in a liter of water. Other solutions were made containing respectively $90,80,70,60,50,40,30,20$ and $10 \mathrm{mg}$. of the dye, and were diluted to 1 liter. The solutions were read independently by each of us against the standard. The readings in percentage, and the average reading of our two observations is given in Table 1.

TABle 1.-Reading of Various Solutions Against a Standard Solution

$00 \mathrm{mg} .=100$ per cent. solution

$90 \mathrm{mg} .=90$ per cent. solution

$80 \mathrm{mg} .=80$ per cent. solution

$70 \mathrm{mg} .=70$ per cent. solution

$60 \mathrm{mg} .=60$ per cent. solution

$50 \mathrm{mg} .=50$ per cent. solution

$40 \mathrm{mg} .=40$ per cent. solution

$30 \mathrm{mg} .=30$ per cent. solution

$20 \mathrm{mg}$. $=20$ per cent. solution

$10 \mathrm{mg} .=10$ per cent. solution

* Too dilute to read = "traces."

$\begin{array}{cccc}\text { Solutions } & \text { Against } & \begin{array}{c}\text { Standard } \\ \text { Average }\end{array} & \text { Solution } \\ \text { Reading 1 } & \text { Reading 2 } & \text { Reading } & \text { Error } \\ \text { Per Cent. } & \text { Per Cent. } & \text { Per Cent. } & \text { Per Cent. } \\ 95 & 90 & 92.5 & 2.5 \\ 80 & 77 & 78.5 & 1.5 \\ 69 & 70 & 69.5 & 0.5 \\ 57 & 60 & 58.5 & 1.5 \\ 52 & 52 & 52.0 & 2.0 \\ 42 & 44 & 43.0 & 3.0 \\ 30 & 34 & 32.0 & 2.0 \\ 24 & 25 & 24.5 & 4.5 \\ * & * & * & *\end{array}$

Unfortunately, in urine such satisfactory readings were not obtained. In certain cases, on the addition of hydrochloric acid and ferric chlorid, a green precipitate occurred. In others, while the diluted urine appeared blue, in the colorimeter it was of a different shade than the standard, thus interfering with the reading. Hence, in several observations no quantitative readings were attempted. Instead, one urine was compared against the other to show the comparative outputs of the two sides.

During the fourth period the indigo-carmin test was made according to Voelcker and Joseph's technic. Twenty c.c. of a 0.4 per cent. solution of the dye in distilled water were injected intramuscularly or intravenously. The time of appearance of blue in the urine was noted, and the total quantity excreted in an hour was estimated colorimetrically in the Duboscq colorimeter.

Finally, a necropsy of the animal was held, and sections from each kidney were hardened in Zenker's fluid for microscopic study. To illustrate the effect of diuresis on the excretion of diastase, the determination was made in several of the experiments both before and 
after the introduction of the sodium chlorid. Indigocarmin and phenolstlphonephthalein were always given in the same animal, either intramuscularly or intravenously, in order to compare their respective rates of excretion by these two forms of injection. The colorimetric estimation of indigocarmin following its intramuscular injection was usually difficult owing to its change in color. This was often obviated by intravenous administration.

The results of these experiments fall into three groups. Group 1 consists of three control animals. Group 2 consists of animals with well-marked nephritis. Group 3 consists of animals showing functional disturbances of the kidney without definite histological changes from the normal. Protocols of these various observations are given.

\section{GROUP 1: CONTROL, ANIMAIS}

EXPERIMENT 4.-Dog 11, weight $16.7 \mathrm{~kg}$. Anesthetized with paraldehyd. Ureteral catheterization after double lumbar incision. Diuresis induced by 150 c.c. of water by stomach-tube, and by intravenous injections of 10 per cent. saline solution. At necropsy, the two kidneys were of equal weight and appeared normal. No abnormal histological changes were found.

\section{TABLE 2.-Findings in Expreriment 4}

\begin{tabular}{|c|c|c|}
\hline & Right Kidney & Left Kidney \\
\hline Amount of urine, first hour. & 18 c.c. & 14 c.c. $\ddagger$ \\
\hline $\begin{array}{l}\text { Specific gravity } \ldots \ldots \ldots \ldots . . . \\
\text { Sodium chlorid per } 100 \text { c.c... }\end{array}$ & 1.015 & 1.013 \\
\hline $\begin{array}{l}\text { Sodium chlorid per } 100 \text { c.c.... } \\
\text { Total chlorid ............... }\end{array}$ & $\begin{array}{l}.48 \mathrm{gm} . \\
86 \mathrm{mg} .\end{array}$ & $67^{.48} \mathrm{mg}$. \\
\hline Nitrogen per 100 c.c.......... & $.40 \mathrm{gm}$ & $.35 \mathrm{gm}$ \\
\hline Total nitrogen .... & $72 \mathrm{mg}$. & $49 \mathrm{mg}$. \\
\hline Diast & & \\
\hline Hydrogen ionization & & 8.7 \\
\hline Phenolsulphonephthalein period: $\dagger$ & & \\
\hline $\begin{array}{l}\text { Amount of urine, second hour } \ldots \ldots \ldots \\
\text { Appearance time of dye... }\end{array}$ & 23 c.c. & $\begin{array}{l}20 \text { c.c. } \\
5 \text { minutes }\end{array}$ \\
\hline Total excretion of dye................... & 22 per cent. & 24 per cent. \\
\hline Indigocarmin period: & & \\
\hline Amount of urine, third hour.. & 20 c.c. & 17 c.c. \\
\hline $\begin{array}{l}\text { Appearance time of dye...... } \\
\text { Total excretion of dye...... }\end{array}$ & $\begin{array}{l}5 \text { minutes } \\
6 \text { per cent. }\end{array}$ & $\begin{array}{l}5 \text { minutes } \\
6 \text { per cent. }\end{array}$ \\
\hline Prussian blue period & & \\
\hline Appearance tim & $11 / 2$ minutes & $1 \frac{1}{2}$ minutes \\
\hline
\end{tabular}

* The diastase reading in this table and others represent the amount of 0.1 per cent. starch solution digested in thirty minutes by 1 c.c. of urine at 37 C. (98.6 F.).

$\dagger$ Phenolsulphonephthalein and indigocarmin given intramuscularly. The indigocarmin excretion was followed for thirty minutes. One specimen of Prussian blue lost. $\$$ Slight loss.

EXPERIMENT 5.-Dog 20, weight $13.3 \mathrm{~kg}$. Anesthetized with paraldehyd. Double lumbar incision followed by ureteral catheterization. Diuresis induced by 200 c.c. of water by stomach-tube and by intravenous injection of 10 per cent. saline solution. At necropsy the two kidneys were of equal weight and appeared normal. No abnormal histological changes were found. 
TABLE 3.-Findings IN EXPERIMENT 5

\begin{tabular}{|c|c|c|}
\hline & Right Kidney & Left Kidney \\
\hline Amount of urine, first hour & 18 c.c. & 19 c.c. \\
\hline $\begin{array}{l}\text { Sodium chlorid per } 100 \text { c.c. } \\
\text { Total chlorid }\end{array}$ & $1.3 \mathrm{gm}$. & $1.4 \mathrm{gm}$ \\
\hline Nitrogen per 100 c.c.......... & $\begin{array}{l}234 \mathrm{mg} . \\
.54 \mathrm{mg} .\end{array}$ & $266 \mathrm{mg}$. \\
\hline Total nitrogen...$\cdots \cdots$ & $97 \mathrm{mg}$. & $121 \mathrm{mg}$. \\
\hline Diastase before diuresis & 64.5 & 64.5 \\
\hline Diastase after diuresis.. & 32 & \\
\hline Freezing-point ...... &.$- .55^{\circ}$ & $-90^{\circ}$ \\
\hline $\begin{array}{l}\text { Hydrogen ionization } \ldots . . . \ldots \ldots \ldots \ldots \\
\text { Phenolsulphonephthalein period :* }\end{array}$ & & 5.7 \\
\hline $\begin{array}{l}\text { Phenolsulphonephthalein period:* } \\
\text { Amount of urine, second hour.. }\end{array}$ & & \\
\hline $\begin{array}{l}\text { Amount of urine, second hour } \\
\text { Appearance time of dye....... }\end{array}$ & 30 c.c. & 60 c.c. \\
\hline Total excretion of dye... & 40 per cent. & 43 per cent. \\
\hline Indigocarmin period: & & \\
\hline Amount of urine, third hour.......... & 55 c.c. & 50 c.c. \\
\hline $\begin{array}{l}\text { Appearance time of dye } \ldots \ldots \ldots \ldots \ldots \ldots \\
\text { Total excretion of dye. } \ldots \ldots \ldots \ldots \ldots\end{array}$ & $\begin{array}{l}14 \text { 45/60 minutes } \\
14 \text { per cent. }\end{array}$ & 14 45/60 minutes \\
\hline Prussian blue period: & & \\
\hline Amount of urine, fourth $h$ & 30 c.c. & 30 c.c. \\
\hline Appearance $\mathrm{t}$ & $1 \min u$ & 1 minute \\
\hline Total & 22 per cent. & 20 per cent (?) \\
\hline
\end{tabular}

* All dyes were given intravenously.

ExPERIMENT 6.-Dog 25, weight $7.5 \mathrm{~kg}$. Anesthetized with paraldehyd. Double lumbar incision followed by ureteral catheterization. Diuresis induced by 200 c.c. of water by stomach-tube and by intravenous injection of 10 per cent. saline solution. At necropsy the two kidneys were of equal weight and appeared normal. No abnormal histological changes were found.

\section{TABLE 4.-Findings IN EXPERIMENT 6}

\begin{tabular}{|c|c|c|}
\hline Amount of urine, first hour & $\begin{array}{l}\text { Right Kidney } \\
27 \text { c.c. }\end{array}$ & $\begin{array}{l}\text { Left Kidney } \\
21 \text { c.c. }\end{array}$ \\
\hline Specific gravity ......... & 1.017 & 1.012 \\
\hline Sodium chlorid per 100 c.c. & $.80 \mathrm{gm}$. & $.84 \mathrm{gm}$. \\
\hline Total chlorid ............. & $216 \mathrm{mg}$. & $176 \mathrm{mg}$. \\
\hline $\begin{array}{l}\text { Nitrogen per } 100 \text { c.c.................. } \\
\text { Total nitrogen }\end{array}$ & $81.30 \mathrm{gm}$ & $.39 \mathrm{gm}$. \\
\hline $\begin{array}{l}\text { Dotal nitrogen } \\
\text { Diastase before diuresis } \ldots \ldots \ldots \ldots \ldots \ldots \ldots\end{array}$ & $32 \mathrm{mg}$ & $32 \mathrm{mg}$ \\
\hline Diastase after diuresis & & \\
\hline Freezing-point $\ldots \ldots$ & $-.910^{\circ}$ & $-1.03^{\circ}$ \\
\hline $\begin{array}{l}\text { Hydrogen ionization } \ldots \ldots \ldots \ldots \ldots \\
\text { Phenolsulohonephthalein period ** }\end{array}$ & & 7.0 \\
\hline $\begin{array}{l}\text { Phenolsulphonephthalein period:* } \\
\text { Amount of urine, second hour. }\end{array}$ & & \\
\hline $\begin{array}{l}\text { Amount of urine, second hour... } \\
\text { Appearance time of dye.......... }\end{array}$ & $\begin{array}{l}16 \text { c.c. } \\
2 \text { minutes }\end{array}$ & $\begin{array}{l}16 \text { c.c. } \\
2 \text { minutes }\end{array}$ \\
\hline Total excretion of dye & 19 per cent. & 15 per cent. \\
\hline $\begin{array}{l}\text { Indigocarmin period: } \\
\text { Amount of urine, } t\end{array}$ & & \\
\hline $\begin{array}{l}\text { Amount of urine, thir } \\
\text { Appearance time of } d y\end{array}$ & $\begin{array}{l}27 \text { c.c. } \\
2 \mathrm{r} / 2 \mathrm{n}\end{array}$ & 25 c.c. \\
\hline & 21 per cent. & 20 per cent. \\
\hline Prussian blue & & \\
\hline $\begin{array}{l}\text { Amount of urine, fourth hour. } \\
\text { Appearance time of dye........ }\end{array}$ & $\begin{array}{l}35 \text { c.c. } \\
13 / 4 \text { minutes }\end{array}$ & $\begin{array}{l}3 j \text { c.c. } \\
13 / 4 \text { minutes }\end{array}$ \\
\hline Total excretion of dye. & & \\
\hline
\end{tabular}

* All dyes were given intravenously. There was leakage of phenolsulphonephthalein at the point of injection.

T Left kidney excreted 10 per cent. more than the right kidney. Accurate estimation impossible on account of difference in color. 
These three experiments show that under the conditions stated the amount of urine normally excreted from hour to hour from the two kidneys was nearly identical. There was considerable variation in both the concentration and total output of chlorid and nitrogen, and, as a result, variation in the molecular concentration as determined by the freezing-point. The amount of diastase from the two sides was the same. Dilution of urine by diuresis had a marked effect on the excretion of this ferment, as was to be expected from Wohlgemuth's and Geraghty, Rowntree and Carey's studies. The acidity of the urine showed only slight differences. The dye substances were all excreted promptly and in corresponding amounts from the two sides. As pointed out by Goodman and Kristeller and by Thomas, the total excretion of indigocarmin was approximately one-half that of phenolsulphonephthalein. The difficulty of quantitating the excretion of potassium ferrocyanid is illustrated by the last two experiments. There is no reason to believe that the amounts excreted from the two sides were different. Yet the precipitate from one kidney was blue and from the other green. Comparative color readings, therefore, were very inaccurate.

\section{GROUP 2: ANIMALS WITH WELL-MARKED NEPHRITIS}

EXPERIMENT 7.-Dog 17 , weight $9.6 \mathrm{~kg}$; $0.8 \mathrm{mg}$. of uranium nitrate $(0.085$ mg. per kilogram body weight) injected into left renal artery according to

TABLE 5.-Findings in Experiment 7

Right Kidney Left Kidney

Amount of urine, first hour.......... 10 c.c. 15 c.c.

\begin{tabular}{|c|c|c|}
\hline fic gravity & & \\
\hline $\begin{array}{l}\text { Specinc gravity } \ldots \ldots \ldots \ldots \\
\text { Sodium chlorid per } 100 \text { c.c... }\end{array}$ & 1.039 & 1.015 \\
\hline $\begin{array}{l}\text { Sodium chiorid per } 100 \text { c.c. } \ldots \ldots \ldots \ldots \\
\text { Total chlorid } \ldots \ldots \ldots\end{array}$ & $1.6 \mathrm{gm}$. & $1.1 \mathrm{gm}$. \\
\hline $\begin{array}{l}\text { Lotal chlorid } \ldots \ldots \text {. } \\
\text { Nitrogen per } 100 \text { c.c. }\end{array}$ & $160 \mathrm{mg}$. & $165 \mathrm{mg}$. \\
\hline Total nitrogen $\ldots \ldots \ldots$ & $2.00 \mathrm{gm}$ & $.42 \mathrm{gm}$. \\
\hline Diastase before diuresis . . . . . . . . . . & 400 & 62.5 \\
\hline Freezing-point & $-3.09^{\circ}$ & $-1.00^{\circ}$ \\
\hline Hydrogen ionization & 5.5 & 8.00 \\
\hline Phenolsulphonephthalein period:* & & \\
\hline Amount of urine, second hour........ & 12 c.c. & 61 c.c. \\
\hline Appearance time of dye $\ldots \ldots \ldots \ldots$. & 6 minutes & 5 minutes \\
\hline $\begin{array}{l}\text { Total excretion of dye } \ldots \ldots \ldots \ldots \ldots \ldots \\
\text { Indigocarmin period: }\end{array}$ & 50 per cent. & 30 per cent. \\
\hline $\begin{array}{l}\text { Indigocarmin period: } \\
\text { Amount of urine, third hour.......... }\end{array}$ & & \\
\hline Appearance time of dye................ & 8 c.c. & 15 c.c. \\
\hline Total excretion of dye............. & 20 per cent. & 13 ner \\
\hline Prussian blue period: & & \\
\hline Amount of urine, fourth hour. . & 16 c.c. & 35 c.c. \\
\hline e of dye. & 4 minutes & 2 minutes \\
\hline & & \\
\hline
\end{tabular}

* All dyes were given intravenously. There was leakage of phenolsulphonephthalein around the point of injection, so when the color first appeared in the urine a second injection was given. Prussian blue in both urines precipitated as a green sediment which could not be read against the standard solution. The two urines, therefore, were compared against each other.

† Identical on both sides.

$\$$ The left kidney excreted 66 per cent. as much as the right. 
method described. Forty-eight hours later anesthetized with paraldehyd. Ureters catheterized after exposure through double lumbar incision. Diuresis induced by 200 c.c. of water by stomach-tube and by intravenous injections of 10 per cent. saline solution. At necropsy, the right kidney was normal. The left kidney was much enlarged, firm, and dark. Microscopic sections from the right kidney, normal. Sections from the left kidney show no glomerular lesions, but marked tubular destruction.

EXPERIMENT 8.-Dog 9, weight $6.2 \mathrm{~kg}$.; $0.6 \mathrm{mg}$. of uranium nitrate $(0.1 \mathrm{mg}$. per kilogram body weight) injected into left renal artery according to the method described. After seventy-two hours, anesthetized with paraldehyd. Ureteral catheterization. Diuresis induced by 200 c.c. of water by stomach-tube and by intravenous injections of 10 per cent. saline solution. At necropsy, both kidneys looked normal. Microscopic sections from the right kidney were not remarkable. Sections from the left kidney showed no glomerular lesions, but marked tubular destruction.

\section{TABLE 6.-FindiNGS IN EXPERIMENT 8}

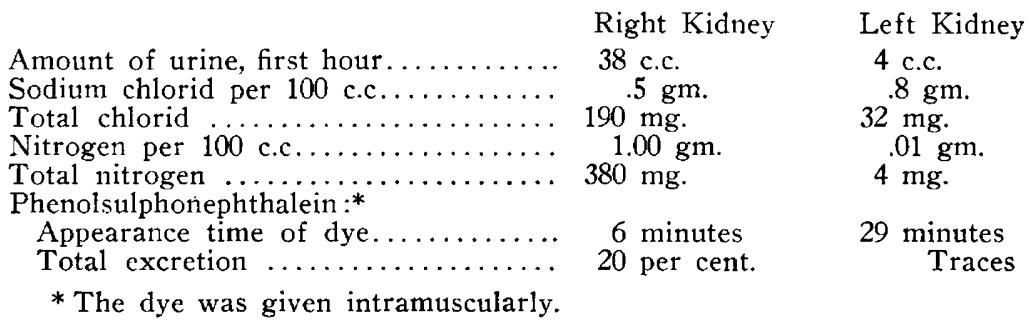

\section{TABLE 7.-Findings in EXPERIMfNT 9}

\begin{tabular}{|c|c|c|}
\hline & Right Kidney & Left Kidney \\
\hline Amount of urine, first hour & 45 c.c. & 4.4 c.c. \\
\hline Specific gravity & 1.014 & 1.006 \\
\hline Sodium chlorid per $100 \mathrm{c} . \mathrm{C}$ & $1.5 \mathrm{gm}$ & $1.2 \mathrm{gm}$. \\
\hline Total chlorid $\ldots \ldots \ldots$ & $675 \mathrm{mg}$. & $52 \mathrm{mg}$. \\
\hline $\begin{array}{l}\text { Nitrogen per } 100 \text { c.c.... } \\
\text { Total nitrogen ........ }\end{array}$ & $.31 \mathrm{gm}$ & $.08 \mathrm{gm}$ \\
\hline $\begin{array}{l}\text { Total nitrogen ......... } \\
\text { Diastase before diuresis }\end{array}$ & $139 \mathrm{mg}$. & $3 \mathrm{mg}$. \\
\hline $\begin{array}{l}\text { Diastase before diuresis } \\
\text { Diastase after diuresis. }\end{array}$ & $\begin{array}{l}62.5 \\
32\end{array}$ & \\
\hline Freezing-point $\ldots \ldots \ldots$ & $-1.08^{\circ}$ & $-.7^{\circ}$ \\
\hline Phenolsulphonephthalein period:* & & \\
\hline Amount of urine $\ldots \ldots \ldots \ldots \ldots \ldots \ldots$ & 40 c.c. & 3 c.c. \\
\hline $\begin{array}{l}\text { Appearance time of dye } \ldots \ldots \ldots \ldots \ldots \ldots \\
\text { Total excretion of dye. } \ldots \ldots \ldots \ldots \ldots \ldots\end{array}$ & $\begin{array}{l}2 \text { minutes } \\
54 \text { per cent. }\end{array}$ & $\begin{array}{l}\text { ninutes } \\
\text { Traces }\end{array}$ \\
\hline & & \\
\hline
\end{tabular}

EXPERIMENT 9.-Dog 24, weight $4.2 \mathrm{~kg}$; $0.5 \mathrm{mg}$. of uranium nitrate $(0.12$ mg. per kilogram body weight) injected into the left renal artery according to the method described. Two and one-half weeks later the animal was anesthetized with paraldehyd and the ureters were catheterized. Diuresis was induced by 200 c.c. of water by stomach-tube and by intravenous injections of $10 \mathrm{per}$ cent. saline solution. At necropsy, the right kidney weighed $24 \mathrm{gm}$. and was normal. The left kidney weighed $17 \mathrm{gm}$., was of firm consistency and pale. The cortex was narrowed, and the kidney markings were obscured. The capsule was stripped with difficulty. Sections from the right kidney were not remarkable. Sections from the left kidney showed a considerable formation 
of scar tissue. Many of the glomeruli were completely destroyed and sclerosed. In parts of the kidney, however, they were less severely damaged and showed the remains of glomerular epithelium with old fibrinous thrombi in the capillaries. In areas through the kidney, no tubular epithelium was left. Here the lumen of the tubules was filled with necrotic material and serum. In other places there was evidence of tubular regeneration as shown by large atypical epithelium. Throughout the entire kidney there was considerable edema.

EXPER1MENT $10 .-$ Dog 18 , weight $11.1 \mathrm{~kg}$; $0.8 \mathrm{mg}$. of uranium nitrate $(0.07$ mg. per kilogram body weight) injected into the left renal artery according to the method described. Twenty-four hours later anesthetized with paraldehyd. Ureteral catheterization. Diuresis induced by 200 c.c. of water by stomach-tube and by intravenous injections of 10 per cent. saline solution. At necropsy the right kidney appeared normal. The left kidney was enlarged, congested, and showed numerous small areas of necrosis. Microscopic sections from the right kidney were normal. Sections from the left kidney showed a few necrotic glomertli, others, with fibrinous thrombi in the glomerular capillaries, and others with edema and hemorrhage into the subcapsular space. The majority of the glomeruli, however, showed no lesions. The tubules throughout the entire kidney were markedly damaged.

\section{TABLE 8.-Findings in Experiment 10}

\begin{tabular}{|c|c|c|}
\hline & Right Kidney & Left Kidney \\
\hline Amount of urine, first hour. & 65 c.c. & 4 c.c. \\
\hline Specific gravity & 1.020 & 1.012 \\
\hline Sodium chlorid per 100 c.c. & $1.5 \mathrm{gm}$. & $1.00 \mathrm{gm}$. \\
\hline Total chlorid ............. & $975 \mathrm{mg}$. & $40 \mathrm{mg}$. \\
\hline Nitrogen per 100 c.c.. & $.70 \mathrm{gm}$ & $.02 \mathrm{gm}$. \\
\hline Total nitrogen & $455 \mathrm{mg}$. & $.8 \mathrm{mg} .(?)$ \\
\hline Diastase before diuresis & 500 & 80 \\
\hline Diastase after diuresis. & 32 & 16 \\
\hline Freezing-point $\ldots \ldots \ldots \ldots$ & $-1.5^{\circ}$ & $-5^{\circ}$ \\
\hline Hydrogen ionization .... & 8.00 & 8.7 \\
\hline \multicolumn{3}{|l|}{ Phenolsulphonephthalein period:* } \\
\hline Amount of urine, second hour. & 70 c.c. & 4 c.c. \\
\hline Appearance time of dye...... & $11 / 2$ minutes & 14 minutes \\
\hline Total excretion of dye.... & 61 per cent. & Traces \\
\hline \multicolumn{3}{|l|}{ Indigocarmin period: } \\
\hline Amount of urine, third hour. & 30 c.c. & 7 c.c. \\
\hline Appearance time of dye..... & 2 minutes & 14 minutes \\
\hline Total excretion of dy & 38 per cent. & Traces \\
\hline \multicolumn{3}{|l|}{ Prussian blue period: } \\
\hline Amount of urine, fourth hou & 40 & $4 \mathrm{c}$ \\
\hline Appearance time of dye.... & $11 / 4$ minutes & 21 minutes \\
\hline Total & 50 per cent. & Traces \\
\hline
\end{tabular}

* All dyes were given intravenously.

EXPERIMENT 11.-Dog 22, weight $13.8 \mathrm{~kg}$; $1.8 \mathrm{mg}$. of turanium nitrate ( $0.13 \mathrm{mg}$. per kilogram body weight) injected into the left renal artery according to the method described. After twenty-four hours, anesthetized with paraldehyd. Ureteral catheterization. Diuresis induced by 200 c.c. of water by stomach-tube, and by intravenous injections of 10 per cent. saline solution. At necropsy, the right kidney was normal; the left kidney was enlarged, dark red in color and of firm consistency. Sections from the right kidney were normal. Sections from the left kidney showed marked hemorrhagic necrosis destroying both tubules and glomeruli. 
TABLE 9.-FindiNGS IN EXPERIMENT 11

\begin{tabular}{|c|c|c|}
\hline & Right Kidney & Left Kidney \\
\hline Amount of urine, first hour & 40 c.c. in $1 \mathrm{hr}$. & $\begin{array}{l}1.6 \text { c.c. in } 4 \mathrm{hrs} \text {. } \\
1.015\end{array}$ \\
\hline & $\begin{array}{l}1.018 \\
1.2 \mathrm{gm} .\end{array}$ & $\begin{array}{l}1.015 \\
1.6 \mathrm{gm} .\end{array}$ \\
\hline & $480 \mathrm{mg}$. & $25 \mathrm{mg}$. \\
\hline r & & \\
\hline & 16 & 32 \\
\hline & $-1.17^{\circ}$ & \\
\hline n pe & & $\begin{array}{l}\text { Alkaline to } \\
\text { phthalein }\end{array}$ \\
\hline $\begin{array}{l}\mathrm{Ar}_{1} \\
\mathrm{Ap} \\
\mathrm{TO}\end{array}$ & $\begin{array}{l}40 \mathrm{ccc} \\
11 / 4 \\
49 \mathrm{pe}\end{array}$ & None in 1 hour \\
\hline ndis & & \\
\hline $\begin{array}{l}\text { Amount of ur } \\
\text { Appearance ti }\end{array}$ & $\begin{array}{l}40 \text { c.c. } \\
11 / 4 \text { minutes }\end{array}$ & None in \\
\hline russian blue period & & \\
\hline $\begin{array}{l}\text { Amount of urine, fours } \\
\text { Appearance time of } \mathrm{dy} \\
\text { Total excretion } \ldots . . .\end{array}$ & $\begin{array}{l}11 / 2 \text { minutes } \\
68 \text { per cent. }\end{array}$ & None \\
\hline
\end{tabular}

* All dyes were given intravenously. It was impossible to determine the indigocarmin excretion quantitatively. The urine from the affected kidney contained considerable blood.

\section{TABLE 10.-Findings IN EXPERIMENT 12}

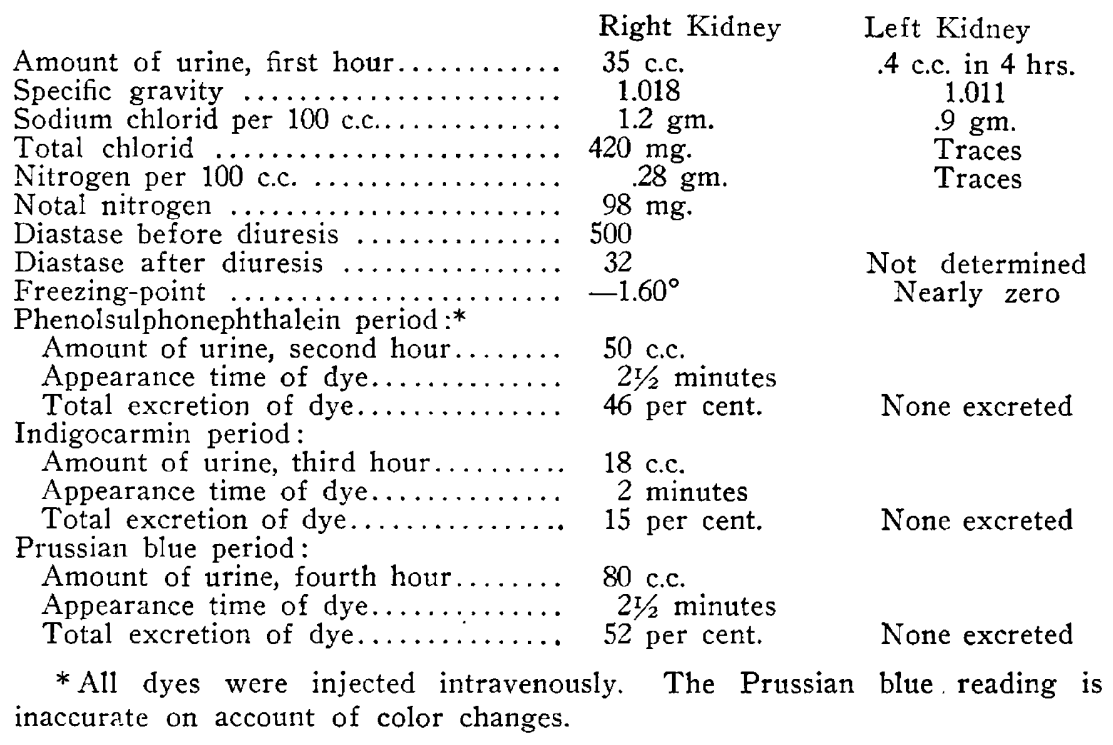

ExPERIment 12.-Dog 23, weight $10.3 \mathrm{~kg}$; $1 \mathrm{mg}$. of uranium nitrate $(0.1 \mathrm{mg}$. per kilogram body weight) injected into the left renal artery according to the method described. Ninety-six hours later, anesthetized with paraldehyd, and ureters catheterized. Diuresis induced by 200 c.c. of water by stomach-tube and by intravenous injections of 10 per cent. saline solution. At necropsy, the right kidney was normal. The left kidney was enlarged and markedly congested. Sections from the left kidney showed areas of hemorrhagic necrosis in which 
both tubules and glomeruli were destroyed. In the greater part of the kidney, the glomeruli were severely damaged. The tubules throughout were filled with cells, serum or necrotic material. The lining epithelium when present was atypical.

EXPERIMENT 13.-Dog 12, weight $11.4 \mathrm{~kg}$; $0.8 \mathrm{mg}$. of uranium nitrate $(0.07$ mg. per kilogram body weight) injected into the left renal artery according to the method described. After forty-eight hours, anesthetized with paraldehyd. Ureteral catheterization. Diuresis induced by 200 c.c. of water by stomachtube and by intravenous injections of 10 per cent. saline solution. At necropsy. the right kidney was normal. The left kidney was much enlarged, dark, and contained scattered areas of necrosis. Microscopic sections from the right kidney were normal. Sections from the left kidney showed a few areas where the glomeruli and tubules were but little damaged. The greater part of the kidney, however, showed acute degenerative changes involving both glomeruli and tubules.

TABLE 11.-Findings IN EXPERIMfint 13

Right Kidney Left Kidney

Amount of urine, first hour.......... 48 c.c.

Specific gravity $\ldots \ldots \ldots \ldots \ldots \ldots \ldots . . . .619$

Sodium chlorid per 100 c.c............. $94 \mathrm{gm}$.

Total chlorid .................... $481 \mathrm{mg}$.

Nitrogen per 100 c.c............... $94 \mathrm{gm}$.

Total nitrogen .................. $481 \mathrm{mg}$.

Diastase after diuresis .............. 32

Freezing-point $\ldots \ldots \ldots \ldots \ldots \ldots \ldots \ldots, 1.65^{\circ}$

Hydrogen ionization $\ldots \ldots \ldots \ldots \ldots \ldots, 8.4$

Phenolsulphonephthalein period :*

Appearance time of dye........... 5 minutes

Total excretion of dye............... 38 per cent.

Indigocarmin period:

Appearance time of dye........... 2 minutes

Prussian blue period:

Appearance time of dye............ $11 / 2$ minutes

Total excretion of dye............. 42 per cent.

* Phenolsulphonephthalein and indigocarmin injected intramuscularly. Indigocarmin gave a greenish color to the urine which was impossible to estimate quantitatively.

These experiments illustrate several of the features which have been discovered in clinical studies on renal function. The amount of urine excreted from the two sides showed marked variations. In the least severe type of nephritis, more urine appeared from the diseased side than from the control kidney. As the lesion progressed the kidney became less able to excrete fluid, and finally became anuric. The specific gravity of the urine from the diseased kidney was always less than from the normal side and had no relation, therefore, to the total fluid excretion. The concentration of sodium chlorid seemed to have no definite relation to the severity of the lesion. In four experiments, it was lower in the pathological kidney's urine than in the control's, but in two cases was higher. The total excretion, however, tended to diminish with an increasing disease. The concentration and total output of nitrogen was a better index of renal function. Both diminished 
strikingly in proportion to the severity of anatomical changes found in the kidney. As the disease progressed, differences in the molecular concentration of the urine increased. As a result, the freezing-point of the urine from the affected side was nearer zero.

The diastase readings are of particular interest. In the two cases in which the determinations were made before diuresis was induced, differences were found which appeared to point out differences in degree of disease. After diuresis, however, the test was of little value. In $\operatorname{Dog} 4$ the diastase reading was higher on the diseased side than on the control side, and equaled the output obtained before sodium chlorid was injected. The dog was practically anuric, and had a marked hematuria. This probably accounts for the atypical finding. In the three cases tested, there was a slight change in the hydrogen ionization of the urine from the diseased side. In two cases it was marked; in one, it was no greater than in the control series. It seems warrantable to believe, however, that in unilateral nephritis the markedly diseased kidney tends to excrete a less acid urine than normal.

The total excretion of the three dye substances was much alike and depended on the severity of the lesion. Potassium ferrocyanid and phenolsulphonephthaiein were excreted with nearly equal rapidity, while indigocarmin was much less completely eliminated. The first experiment illustrates that the appearance time of a dye in the urine may give misieading information. In this animal the diseased kidney put out more urine than the normal, and the dyes from the injured side came to the urine as soon as from the control side or even sooner, although the total excretion was considerably less. In the more advanced cases, the appearance time of all the dyes from the diseased side was delayed in proportion to the severity of the lesion.

Therefore, these experiments showed that with an increasingly severe nephritis, the urine from the affected side became more dilute. The excretion of nitrogen diminished in proportion to the severity of the lesion. The excretion of chlorid was more variable. Differences in the freezing-point of the compared urines showed the diseased side and, in a general way, afforded a quantitative test for the function of the two kidneys. This determination, however, was not so accurate a test for renal function as the comparative output of nitrogen or dyes.

The excretion of the three dyes which were used afforded a good index of disturbed function. Phenolsulphonephthalein was eliminated more completely and was simpler to estimate quantitatively than indigocarmin or potassium ferrocyanid. The excretion of diastase gave valuable information in regard to the degree of renal injury except when there were marked differences in the amount of urine which came from the two kidneys. 


\section{GROUP 3: ANIMALS WITHOUT NEPHRITIS BUT WITH ABNORMAL RENAL FUNCTION}

EXPERIMENT 14.-Dog 14, weight $10.5 \mathrm{~kg}$; $0.6 \mathrm{mg}$. of uranium nitrate $(0.06$ mg. per kilogram body weight) injected into the left renal artery according to the method described. After twenty-four hours, anesthetized with paraldehyd.

TABLE 12.-.-Findings in Experiment 14

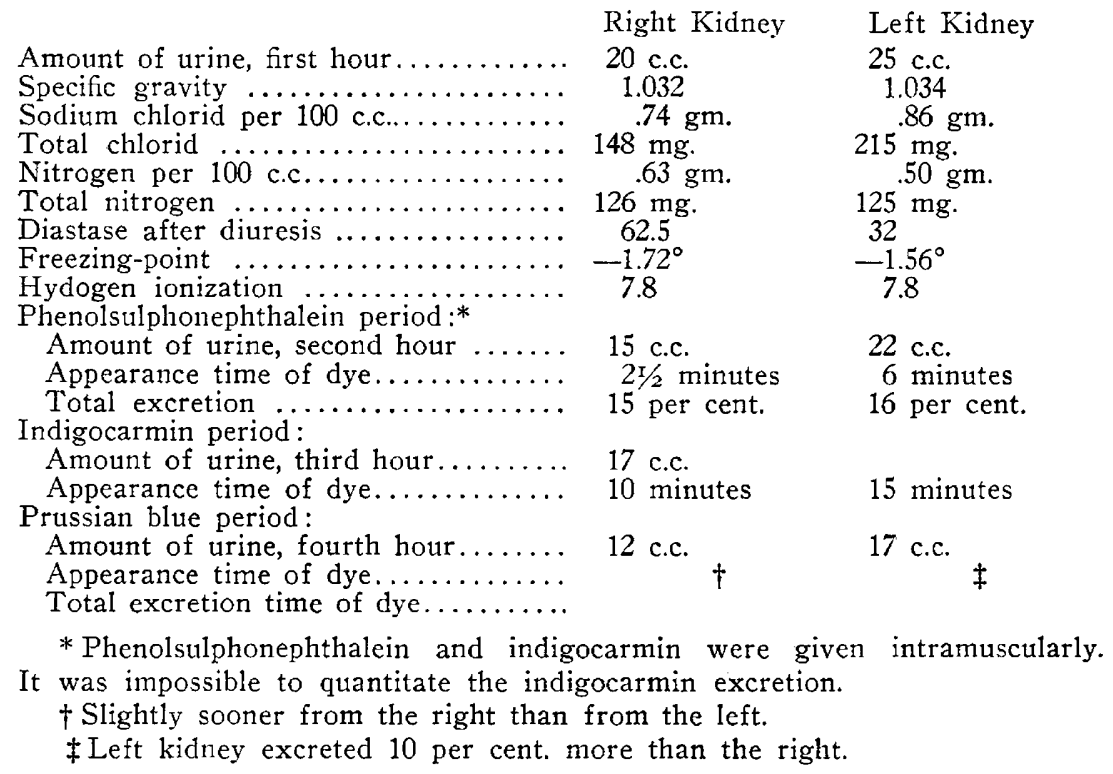

\section{TABLE 13.-FindiNGS IN EXPERIMENT 15}

Right Kidney

Amount of urine, first hour........... 23 c.c.

Specific gravity $\ldots \ldots \ldots \ldots \ldots \ldots \ldots, \quad 1.012$

Sodium chlorid per 100 c.c............. $1.5 \mathrm{gm}$.

Total chlorid ..................... $345 \mathrm{mg}$.

Nitrogen per 100 c.c..................

Total nitrogen $\ldots \ldots \ldots \ldots \ldots \ldots \ldots \ldots, 101 \mathrm{mg}$.

Diastase after diuresis ................. 24

Freezing-point $\ldots \ldots \ldots \ldots \ldots \ldots \ldots \ldots,-1.45^{\circ}$

Hydrogen ionization ............... 8.3

Phenolsulphonephthalein period:*

Amount of urine, second hour....... 50 c.c.

Appearance time of dye............. 1 minute

Total excretion of dye................ 51 per cent.

Indigocarmin period:

Amount of urine, third hour......... 14 c.c.

Appearance time of dye................ 14 minute

Total excretion of dye............. 25 per cent.

Prussian blue period:

Amount of urine, fourth hour....... 17 c.c. 18 c.c.

Appearance of dye.................. 1 minute

Total excretion of dye.............

.............

Left Kidney

33 c.c.

1.008

$1.2 \mathrm{gm}$.

$396 \mathrm{mg}$.

$.32 \mathrm{gm}$.

$106 \mathrm{mg}$.

16

$-1.05^{\circ}$

8.3

60 c.c.

1 minute

45 per cent.

20 c.c.

1 minute

25 per cent.

1 minute

$\dagger$

* All dyes were given intravenously.

$\dagger$ Left kidney excreted 10 per cent. more than the right. 
Ureteral catheterization. Diuresis induced by 200 c.c. of water by stomachtube, and by intravenous injections of 10 per cent. saline solution. At necropsy the two kidneys appeared normal and were of equal weight. Sections from the left kidney showed no evidence of an acute lesion.

EXPERIMENT 15.-Dog 16, weight $7.6 \mathrm{~kg}$; 1 c.c. of normal salt solution was injected into the left renal artery according to the method described. Twentyfour hours later the animal was anesthetized with paraldehyd. Ureteral catheterization. Diuresis induced by 200 c.c. of water by stomach-tube, and by intravenous injections of 10 per cent. saline solution. At necropsy the two kidneys appeared normal and were of equal weight. Sections from the left kidney showed no evidence of an acute lesion.

EXPERIMENT 16.-Dog 19, weight $10 \mathrm{~kg}$; $0.9 \mathrm{mg}$. of uranium nitrate $(0.08$ mg. per kilogram body weight) injected into the left renal artery according to the method described. There was slight leakage at the point of injection. After forty-eight hours, anesthetized with paraldehyd. Ureteral catheterization. Diuresis induced by 200 c.c. of water by stomach-tube, and by intravenous injection of 10 per cent. saline solution. At necropsy the two kidneys were of equal weight and appeared normal. Microscopic sections from the right kidney were negative. Sections from the left kidney were not remarkable except for a few foci of round-cell infiltration. There was no evidence of any acute lesion.

\section{TABLE 14-FindiNGS IN EXPERIMENT 16}

\begin{tabular}{|c|c|c|}
\hline \multicolumn{3}{|c|}{ Kidney } \\
\hline Amount of urine, first hour & 15 c.c. & \\
\hline avity $\ldots \ldots \ldots . . . .$. & $\begin{array}{l}1.007 \\
1.24 \mathrm{gm} .\end{array}$ & 1.004 \\
\hline otal chlorid ............. & $\begin{array}{l}1.24 \mathrm{gm} . \\
186 \mathrm{mg} .\end{array}$ & $\begin{array}{l}1.5 \mathrm{gm} . \\
450 \mathrm{mg} \text {. }\end{array}$ \\
\hline gen per 100 c.c. & $.43 \mathrm{gm}$ & $.27 \mathrm{gm}$ \\
\hline $\begin{array}{l}\text { nitrogen } \\
\text { e before }\end{array}$ & $64 \mathrm{mg}$. & $81 \mathrm{mg}$. \\
\hline before & ${ }^{64} 8$ & $\begin{array}{r}64 \\
8\end{array}$ \\
\hline $\begin{array}{l}\text { Dia } \\
\text { Fre }\end{array}$ & $-1.63^{\circ}$ & $\begin{array}{r}8 \\
-1.33^{\circ}\end{array}$ \\
\hline Hyd & 7.8 & 7.8 \\
\hline lein $\mathrm{F}$ & & \\
\hline $\begin{array}{l}\text { Amount of urine, second hour....... } \\
\text { Appearance time of dye.................. }\end{array}$ & 20 c.c. & 50 c.c. \\
\hline Tot & $\begin{array}{l}11 / 2 \text { minutes } \\
35 \text { per cent. }\end{array}$ & $\begin{array}{l}11 / 2 \text { minutes } \\
38 \text { per cent. }\end{array}$ \\
\hline Indig & & \\
\hline $\begin{array}{l}\mathrm{Ap} \\
\mathrm{TC}\end{array}$ & $2 \mathrm{n}$ & $2 \mathrm{mi}$ \\
\hline $\begin{array}{l}\text { Total excreti } \\
\text { Prussian blue }\end{array}$ & & $26 n d>$ \\
\hline Amol & 20 & \\
\hline & & \\
\hline
\end{tabular}

* All dyes were given intravenously. It was impossible to estimate either the total or comparative output of potassium ferrocyanid on account of differences in color.

Experiment 17.-Dog 15, weight $9.6 \mathrm{~kg}$.; $0.6 \mathrm{mg}$. of uranium nitrate $(0.06$ mg. per kilogram body weight) injected into the left renal artery according to the method described. Five days later anesthetized with paraldehyd. Ureteral catheterization. Diuresis induced by 200 c.c. of water by stomach-tube, and by intravenous injections of 10 per cent. saline solution. At necropsy, the two kidneys were of equal weight and appeared normal. No abnormal histological changes were found.

ExPERIMENT 18.-Dog 26, weight $7.2 \mathrm{~kg}$. The left kidney was exposed and handled as usual without injection of the renal artery. Twenty-four hours later the animal was anesthetized with paraldehyd and the ureters were catheterized. Dituresis was induced by 200 c.c. of water by stomach-tube and by intravenous 
injections of 10 per cent. saline solution. At necropsy, the two kidneys were of equal weight and appeared normal. Nothing abnormal was found in either kidney by histological examination.

\section{TABLE 15.-Findings in EXPeriment 17}

Right Kidney

$\begin{array}{ll}\text { Amount of urine, first hour............ } & 16 \text { c.c. } \\ \text { Specific gravity ......................... } & 1.033\end{array}$

Sodium chlorid per 100 c.c.......... $.60 \mathrm{gm}$.

Total chlorid ...................... $96 \mathrm{mg}$.

Nitrogen per 100 c.c................ $.46 \mathrm{gm}$.

Total nitrogen .................... $73 \mathrm{mg}$.

Diastase after diuresis ............... 64

Freezing-point $\ldots \ldots \ldots \ldots \ldots \ldots \ldots \ldots, \ldots \ldots \ldots, 2.31^{\circ}$

Hydrogen ionization .............. 8.0

Phenolsulphonephthalein period:*

Amount of urine, second hour....... 15 c.c.

Appearance time of dye............. 4 minutes

Total excretion of dye................ 30 per cent.

Indigocarmin period:

Amount of urine, third hour..........

Appearance time of dye...............

Total excretion of dye..............

Prussian blue period:

Amount of urine, fourth hour.........

Appearance time of dye...............

Total excretion of dye..............

22 c.c.

$\dagger$

18 per cent.

12 c.c.

$\ddagger \quad 32$ c.c.

45 c.c.

$\dagger$

* Phenolsulphonephthalein and indigocarmin were given intramuscularly. It was impossible to determine accurately the relative or absolute amounts of potassium ferrocyanid excreted on account of color changes.

† Identical on both sides.

$¥$ Slightly sooner from the right kidney than from the left. Left kidney excreted considerably more than the right.

\section{TABLE 16.-Findings in EXPERIMENT 18}

Right Kidney

18 c.c.

1.017

$1.6 \mathrm{gm}$.

$288 \mathrm{mg}$.

$.62 \mathrm{gm}$

$117 \mathrm{mg}$.

32

$-1.35^{\circ}$

Freezing-point $\ldots \ldots \ldots \ldots \ldots \ldots \ldots \ldots \ldots$
Hydrogen ionization $\ldots \ldots \ldots \ldots \ldots \ldots$

Phenolsulphonephthalein period:

Amount of urine, second hour........ 16 c.c.

Appearance time of dye............. $21 / 2$ minutes

Total excretion of dye.............., 40 per cent.

Indigocarmin period:

Amount of urine, third hour.........

Appearance time of dye...............

Total excretion of dye................

Prussian blue period:

Amount of urine, fourth hour........

Appearance time of dye................

Total excretion of dye...............
25 c.c.

$13 / 4$ minutes

20 per cent.

42 c.c.

2 minutes

.....
Left Kidney

45 c.c.

$1.00 \mathrm{gm}$.

$450 \mathrm{mg}$.

$139 \mathrm{mg}$.

32

$-2.00^{\circ}$

5.5

45 c.c.

$41 / 4$ minutes

35 per cent.

18 per cent.

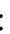

* Left kidney excreted nearly twice as much as right. Accurate estimation impossible on account of differences in color. 
The striking feature in the last series of experiments was the pronounced polyuria occurring from the side which had been manipulated. It occurred during each of the four hours of observation and se cannot be attributed to a normal variation in the amount of urine excretecl. The specific gravity of the urine from the polyuric kidney was always the lower. Both the concentration of sodium chlorid and its total output varied widely. But in every instance, the total output of sodium chlorid from the abnormal side was greater than from the control side. The concentration of nitrogen from the diseased kidney was lower in every case than from the normal kidney. The total output for the period, however, was considerably highly than on the control side. In every case, the freezing-point was lower in the normal urine than in the urine from the polyuric kidney, which showed that the kidney with polyuria secreted a urine of less molecular concentration than normal. As might be expected from the previous notes, the diastase readings were insignificant. In two cases, the reaction of the urine was more acid from the diseased side than from the control. In the other cases the hydrogen ionization of the two urines was the same. As in the preceding experiments, the excretion of dyes from the two kidneys was parallel. In the case with the least polyuria, the appearance time of all the dyes from the affected kidney was delayed. In the remaining experiments, the dyes appeared in the two urines at approximately the same time. The total amount of dye excreted from the two kidneys in each instance was nearly the same. In certain of the experiments one or another dye appeared to be excreted from the diseased side in an amount above normal.

Thus, these experiments are radically different from those observations in which the kidney was definitely diseased. Here the amount of urine, nitrogen and chlorid which was excreted from the injured kidney was greater than from the control side, and the amount of dyes put out was at least normal. The explanation of these findings is uncertain. Further studies in this condition are necessary to understand its significance.

\section{SUMMARY}

Experiments have been undertaken to compare, on the same animal, the tests for renal function which are most commonly used in studying unilateral disease. Nephritis was produced by the injection of uranium nitrate into the renal artery of one kidney, according to the method of Ribbert and Baehr. By this procedure, one-sided lesions of varying intensity were caused.

The results of these experiments fall into two groups. One group consists of animals whose kidneys anatomically were normal yet functionally were pathological. The functional condition encountered suggested a hyperpermeability of the kidney to water, chlorid, nitrogen 
and in certain instances, to various dyes. No explanation for these findings is offered.

The other group of experiments consists of animals in which a well-marked nephritis was produced. In these animals, tests for renal function were applied and gave results similar to those which have been reported in human beings.

Clinical studies have suggested that a close parallelism exists between the degree of kidney destruction and the kidney's ability to excrete various solid substances; and that all the tests most commonly used in the study of renal function give parallel results. The experiments reported demonstrate by a variety of tests for renal function made on the same animal at the same time that such a parallelism does exist, but that certain of the tests are more significant than others.

The total excretion of nitrogen from one kidney over a given period of time, as compared with its excretion from the other kidney, gives accurate information in regard to the existence and degree of disease. The comparative excretion of diastase from the two kidneys is a valuable test for renal function when the amount of urine from the two kidneys is nearly the same. This test has a striking disadvantage. Dilution of urine produces such marked differences in the diastase excretion that when the urine from the two kidneys is excreted in different amounts the observation becomes valueless. As the renal disease advances and the urine becomes more dilute, the freezingpoint approaches zero. This determination, however, is not so sharp a quantitative test for renal function as the excretion of nitrogen or dye substances.

Of the two dyes commonly used, phenolsulphonephthalein is the better. It can be injected in small bulk, is excreted rapidly from the kidneys, and the amount put out can be quantitated accurately. Indigocarmin does not show changes in renal function which are not demonstrated by phenolsulphonephthalein, and has two disadvantages. It requires a considerable amount of injection fluid and its excretion is difficult to read colorimetrically. The latter objection can be obviated, in part, by intravenous administration of the dye. The excretion of potassium ferrocyanid parallels that of phenolsulphonephthalein and indigocarmin, but is more difficult to estimate colorimetrically. Hence, for practical purposes, it is of no value as a test for renal function. The reaction of the urine from a severely diseased kidney apparently tends to become less acid than that from the normal side. This variation, however, is not sufficiently marked to be used as a functional test for one-sided disease.

It appears, therefore, from the foregoing experimental observations, that renal function is best estimated by the determination of nitrogen excretion and by the phenolsulphonephthalein test. 